\title{
PENDIDIKAN KARAKTER BERBASIS EDUCARE DI PAUD SAI PREMA KUMARA DENPASAR
}

Oleh:

\author{
W.A. Sindhu Gitananda, Ni Luh Putu Trisdyani \\ sindhugitananda@gmail.com, trisdyani@unhi.ac.id \\ Fakultas Pendidikan Universitas Hindu Indonesia \\ Denpasar
}

Proses Review 1-5 September, Dinyatakan Lolos 7 September

\begin{abstract}
Character is the most important issue in education today. PAUD Sai Prema Kumara is a school that focuses its greatest attention on the character of students. This commitment is translated into a learning pattern known as educare. This term is then translated into a number of learning implementation strategies, namely the cultivation of self-discipline through yoga or meditation-based learning, daily praxis in the form of good thinking, good saying, and good doing, and instilling the values of love for others at every opportunity. In addition, teacher modeling at school and the involvement of parents or family are the main keys to the formation of educare-based characters in PAUD Sai Prema Kumara Denpasar. All of these things can be seen to be very supportive of students in forming the personal antichatexis and the ego-ideal.
\end{abstract}

Keywords: Character, Education, PAUD, Educare, Psychoanalysis

\begin{abstract}
Abstrak
Karakter menjadi isu terpenting dunia pendidikan saat ini. PAUD Sai Prema Kumara adalah sebuah sekolah yang memokuskan perhatian terbesarnya kepada karakter siswa. Komitmen tersebut diterjemahkan menjadi pola pembelajaran yang disebut sebagai educare. Istilah ini kemudian diterjemahkan ke dalam beberapa strategi penerapan pembelajaran, yaitu penanaman disiplin diri melalui pembelajaran berbasis yoga atau meditasi, praksis keseharian berupa berpikir, berkata, dan berbuat yang baik, serta penanaman nilai-nilai cinta kasih kepada sesama dalam setiap kesempatan. Selain itu, keteladanan guru di sekolah dan keterlibatan para orang tua atau keluarga menjadi kunci utama pembentukan karakter berbasis educare di PAUD Sai Prema Kumara Denpasar. Semua hal tersebut dapat dipandang sangat menunjang siswa dalam membentuk antikateksisantikateksis pribadi dan ego-ideal.
\end{abstract}

Kata kunci: Karakter, Pendidikan, PAUD, Educare, Psikoanalisis 


\section{PENDAHULUAN}

Karakter dan kepribadian menjadi kunci keberhasilan manusia bereksistensi. Dalam karakter tersimpan kode-kode yang selalu dapat digunakan mengidentifikasi seseorang. Karakter tersebut menjadi penanda kepribadian seseorang (bdk. Chaplin, 2000:82; 362). Semuanya itu berkaitan dengan hubungan antara id, ego, dan superego dalam terminologi psikoanalisis. Jung menjelaskan bahwa kepribadian merupakan integrasi dari ego, kesadaran pribadi, dan ketidaksadaran kolektif, kompleks-kompleks, arketip-arketip, persona dan anima (Chaplin, 2000:362). Untuk dapat membentuk karakter dan kepribadian tersebut oleh karena itu dibutuhkan pendidikan yang menyeluruh, karena melibatkan tidak hanya individu tersebut, tetapi juga lingkungan, bahkan mitos-mitos yang berkembang di daerah sekitar. Dewasa ini, pendidikan dimaksud diistilahkan sebagai pendidikan karakter.

Pendidikan karakter adalah sebuah usaha untuk mendidik anak-anak agar dapat mengambil keputusan dengan bijak dan mempraktikkannya dalam kehidupan seharihari, sehingga mereka dapat memberikan kontribusi yang positif kepada lingkungan (Megawangi, 2004:49; dalam Kusuma, dkk. 2011:5). Dengan demikian, pendidikan karakter adalah suatu sistem penanaman nilai-nilai karakter yang baik kepada semua yang terlibat dan sebagai warga sekolah, sehingga mempunyai pengetahuan, kesadaran, dan tindakan dalam melaksanakan nilai-nilai tersebut. Oleh karena itu, pendidikan karakter sangat penting untuk diterapkan sedini mungkin, mengingat banyaknya kasus yang melibatkan para pelajar, terutama pada rentang usia remaja.

Penanganan yang tepat dan menyeluruh dibutuhkan yaitu dengan meningkatkan proses "pendidikan karakter yang berkarakter", menanamkan nilai-nilai yang memiliki karakter baik, baik itu di lingkungan keluarga, lingkungan sekolah maupun lingkungan masyarakat, sampai berbangsa dan bernegara. Sehingga penting untuk dibangun suatu pendidikan karakter dengan membangkitkan sifat-sifat terbaik yang melekat pada diri setiap orang, guna menumbuhkembangkan jiwa-jiwa "kedewataan" (baca: karakter baik) manusia melalui media "pendidikan bathin". Suatu pendidikan yang dapat menampilkan sifat-sifat terbaik secara menyeluruh yang ada di dalam kepribadian (personality) seorang anak atau manusia.

Segala hal yang dilakukan oleh orang dewasa pasti akan ditiru oleh anak yang masih kanakkanak. Sedikit saja ada kesalahan maka akan berakibat fatal bagi perkembangan anak dan sulit untuk dibenahi. Sekali lagi, solusi sejak dini yang paling memungkinkan adalah pendidikan anak usia dini (PAUD). Demi tujuan solutif ini, salah satu PAUD yang telah terbukti memiliki kemampuan dalam membentuk karakter anak adalah PAUD Sai Prema Kumara Denpasar. Hal ini kemudian dibuktikan juga dengan raihan akreditasi A, dengan SK BAN PAUD dan PNF terbaru NOMOR: 150/BAN PAUD DAN PNF/ AKR/2019.

PAUD Sai Prema Kumara Denpasar adalah satu-satunya PAUD di Denpasar yang menerapkan model pembelajaran "educare" berbasis Hindu. Menurut Kepala PAUD Sai Prema Kumara Denpasar (Wyn. Wijania dalam wawancara pada tanggal 12 Januari 2020 jam 11 Wita), PAUD Sai Prema Kumara Denpasar lebih menekankan kepada educare (pengembangan potensi anak) seperti melukis, menabuh, menari, menggambar dll. Menurut keterangan Wijania, banyak lulusan dari PAUD ini tidak mampu berhitung, membaca dan menulis. Namun hal tersebut tidak menjadi masalah karena lulusan PAUD ini siswanya memiliki suatu bakat masing-masing. Menurut Kepala PAUD Sai Prema Kumara Denpasar ini, PAUD tersebut mengajarkan agar anak didiknya memiliki nilai-nilai kemanusiaan yang tinggi yaitu anak memiliki sifat yang bajik sehingga anak dapat memilih dan memilah mana hal yang positif yang bermanfaat bagi dirinya dan mana hal yang negatif yang dapat merugikan dirinya. Dengan demikian, pembelajaran yang diterapkan di PAUD ini sangat sejalan dengan prinsip-prinsip pendidikan karakter, bahkan unik jika dibandingkan dengan PAUD-PAUD yang lain yang lebih mengutamakan pendidikan akademik yang menekankan agar siswa mampu membaca, menulis, dan berhitung. Oleh karena itu, pendidikan karakter berbasis educare di PAUD Sai Prema Kumara Denpasar dipandang 
menarik untuk dikaji secara deskriptif-kualitatif (penggambaran secara mendalam) menarik untuk dibahas dalam artikel ini.

\section{METODE PENELITIAN}

Suyanto (2012:1) memandang bahwa anak usia dini memiliki perkembangan paling cepat dalam berbagai aspek, termasuk aspek agama, moral, sosial, intelektual, dan emosi. Selain itu juga ia berpandangan bahwa segala yang diperoleh anak pada usia dini akan terpateri kuat di dalam hati dan pikiran mereka. Silahuddin (2017:38) menyoroti pentingnya peran keluarga dalam pembangunan karakter anak yang menghindarkannya dari perbuatanperbuatan yang dilarang agama. Di samping itu, peran pendidik juga tidak kalah pentingnya, yaitu dengan menciptakan lingkungan belajar yang kondusif yang menunjang anak untuk mengeksplorasi dirinya dan pengalaman belajar sesuai minat dan bakatnya.

Kemudian Wulandari, dkk. (2014) mendeskripsikan tingkat efektivitas implementasi pendidikan karakter berbasis nilai-nilai kemanusiaan pada anak usia dini di PAUD Sai Prema Kumara Denpasar ditinjau dari komponen konteks, input, proses, dan produk. Penelitian ini menggunakan pendekatan kuantitatif dengan penekanan kepada aspek evaluatif yang hasilnya secara deskriptif menunjukkan tingkat efektivitas komponen konteks dengan kriteria sangat efektif, juga termasuk komponen input, proses, dan produk yang juga sangat efektif. Dengan demikian, PAUD Sai Prema Kumara Denpasar memang sangat layak dijadikan lokasi penelitian dalam kaitan dengan pendidikan karakter.

PAUD adalah suatu upaya pembinaan yang ditujukan kepada anak sejak lahir sampai dengan usia enam tahun yang dilakukan melalui pemberian rangsangan pendidikan untuk membantu pertumbuhan dan perkembangan jasmani dan rohani agar anak memiliki kesiapan dalam memasuki pendidikan lebih lanjut. PAUD itu ada dua yaitu Playgroup (kelompok bermain) dan Taman Kanak-Kanak (TK). Playgroup (kelompok bermain) merupakan satuan pendidikan anak usia dini pada jalur pendidikan non formal yang menyelenggarakan pendidikan bagi anak usia di bawah lima tahun. Taman Kanak-Kanak (TK) adalah jenjang pendidikan anak usia dini (yakni usia 6 tahun atau di bawahnya) dalam bentuk pendidikan formal (id.m.wikipedia.org/wiki/Taman_Kanak-

kanak). PAUD Sai Prema Kumara adalah salah satu nama PAUD yang berada di Desa Tonja, Denpasar Utara. Di samping itu, PAUD ini adalah satu-satunya PAUD yang menerapkan model pembelajaran educare berbasis pendidikan agama Hindu demi mengembangkan/ membangkitkan potensi dari siswa. Oleh karena itu, lokus penelitian ini layak diobservasi dan untuk lebih mendalami penerapan dan hasil penerapan model pembelajaran educare, subjeksubjek yang terdapat di dalamnya, seperti guru, siswa, dan orang tua siswa diwawancara secara mendalam.

Pemahaman terhadap data dibingkai sesuai konsep-konsep teori konvergensi dan psikoanalisis. Berdasarkan teori konvergensi, perkembangan anak didik dipengaruhi oleh kedua faktor tersebut yaitu pembawaan sejak lahir dan pengaruh lingkungan. William Stern juga mengatakan bahwa anak dilahirkan dengan pembawaan baik maupun buruk, dan kemudian lingkungan akan mempengaruhi pembawaan itu lebih lanjut (Tim, 2012:15). Teori konvergensi meyakini bahwa seberapa baiknya potensi bawaan anak didik, masih harus dilengkapi dengan lingkungan dan pendidikan yang baik untuk membina dan bisa menjadikan sebuah pribadi yang baik dan ideal. Perkembangan anak didik dipengaruhi oleh dua faktor yaitu faktor internal, yaitu faktor dari dalam diri anak didik seperti pembawaan, dan faktor eksternal, yaitu faktor lingkungan (ibid, 2012:17). Faktor-faktor tersebut lebih lanjut dipahami berdasarkan teori psikoanalisis yang menekankan pentingnya peran keluarga dalam membentuk superego seseorang yang kemudian memberi semacam antikateksis-antikateksis yang menekan id dan membentuk ego-ideal (Hall, 2019:83).

\section{ANALISIS DAN INTERPRETASI DATA}

\subsection{Pendidikan Karakter Berbasis Educare}

Secara etimologi makna pendidikan sangat berkaitan dengan kata 'educare' dalam bahasa 
latin yang bermakna melatih atau mengajarkan. Educare berasal dari kata ex dan ducare, yang berarti memimpin. Orang Romawi melihat pendidikan sebagai educare, yaitu mengeluarkan dan menuntun, tindakan merealisasikan potensi anak yang dibawa waktu dilahirkan di dunia. Bangsa Jerman melihat pendidikan sebagai Erziehung yang setara dengan educare, yakni membangkitkan kekuatan terpendam atau mengaktifkan kekuatan/ potensi anak (Rohman, 2011:5).

Sai Baba pada tanggal 20 September 2000 mengungkapkan pendidikan (education) memiliki dua aspek yaitu yang pertama terkait dengan pendidikan luar atau duniawi, yang hanya berkaitan dengan pengetahuan bersifat tekstual (buku) (Budiasa, 2012). Di dunia modern kita banyak menemukan orang pintar dan hebat dalam hal pendidikan. Aspek yang kedua adalah dikenal dengan educare yang berkaitan dengan nilai kemanusiaan. Kata educare mengandung makna membawa keluar apa yang ada di dalam. Educare berarti membawa keluar nilai kemanusiaan. "Membawa keluar" berarti menerjemahkan nilai tersebut dalam tindakan (Budiasa, 2012).

Jadi pendidikan karakter berbasis educare merupakan suatu penerapan model pembelajaran yang diterapkan di PAUD Sai PremaKumaraDenpasardalammengembangkan potensi anak yang dibawa sejak lahir dengan membangkitkan minat dan bakat dari anak tersebut. Prinsip dasarnya adalah seorang anak/ siswa sudah memiliki minat dan bakat tersendiri terhadap sesuatu. Model pembelajaran educare dipandang memberi peluang sangat besar kepada peran pihak sekolah dalam membantu pengembangan minat dan bakat siswa tersebut. Dalam kegiatan penerapan model ini, fokus utama pembelajaran pada PAUD ini secara garis besar adalah membangun karakter siswa sesuai dengan ajaran Hinduisme yang diterjemahkan dalam berbagai bentuk tindakan-tindakan yang sesuai dengan pemahaman siswa PAUD.

\subsection{Faktor-faktor Pendorong Pihak PAUD Sai Prema Kumara Menerapkan Educare}

Berdasarkan hasil observasi dan studi dokumen, faktor pendorong penerapan model pembelajaran educare di PAUD Sai Prema Kumara pertama-tama dipertimbangkan bahwa usia anak pra-sekolah (3-6 tahun) merupakan masa yang paling strategis dalam pendidikan (pembentukan karakter) anak. Pada usia ini anak paling sensitif terhadap lingkungan. Untuk itu, pada usia ini para siswa sangatmembutuhkan segala hal yang bersinggungan dengan pengembangan diri dan pembentukan karakter anak hingga menjadi manusia dewasa yang memiliki mental yang baik.

Secara formal, Undang-Undang No. 20 Tahun 2003 Tentang Sistem Pendidikan Nasional mengatur bahwa Pendidikan Anak Usia Dini (PAUD) dapat diselenggarakan melalui jalur formal, nonformal, dan informal (Pasal 28 ayat 2) UU Tahun 2003 ini telah mendorong tumbuhnya lembaga PAUD dalam berbagai bentuk layanan dengan kualitas yang sangat beragam. Kelembagaan tersebut dimaksudkan untuk memenuhi kebutuhan masyarakat akan layanan PAUD (Wijania, 2014:4). Berdasarkan keterangan kepala sekolah, di zaman sekarang ini sangat diperlukan pendidikan yang mengutamakan pada pembentukan karakter yang baik, karena sesungguhnya tujuan akhir dari pendidikan adalah karakter siswa. Ia mengingatkan bahwa di zaman globalisasi ini, negara ini tidak kurang dengan orang pintar, namun sangat kekurangan dengan orang yang berkarakter baik.

Terlebih lagi, pemerintah Republik Indonesia, melalui Presiden Joko Widodo menyerukan slogan "Revolusi Mental". Kepala sekolah juga menekankan bahwa orang pintar yang tidak dibekali dengan moral dan karakter yang baik akan menjadi sangat berbahaya bagi masa depan bangsa. Ilmu pengetahuan diibaratkan dengan sebilah pisau yang tajam. Pisau tersebut dapat bermanfaat dan dapat pula sangat membahayakan, tergantung siapa yang memakai pisau tersebut. Pisau yang tajam jika di tangan yang tepat maka akan tepat gunanya. Oleh karena itu, orang yang memiliki pengetahuan baik juga harus memiliki karakter baik. Jadi jelas, secara formal PAUD Sai Prema Kumara telah merespon segala situasi dan kondisi bangsa dan negara dengan sangat baik melalui penerapan ajaran-ajaran agama Hindu sebagai dasar model pembelajaran educare. 
Kemudian, secara historis, berawal dari niat tulus dan mulia dari pengurus SSG (Sai Study Group) Denpasar yang ingin ikut terlibat dalam pelayanan dan pengabdian dalam bidang pendidikan untuk masa depan bangsa dan negara yang lebih damai, adil dan makmur, maka diajukanlah sebuah proposal untuk meningkatkan kualitas/mutu pelayanan, pembinaan serta pengembangan Sai Spiritual dan Education (SSE) yang dilaksanakan di SSG Denpasar, kepada Yayasan Sri Satya Sai Bali (YSSB) pada tanggal 3 Januari 2002.

Berdasarkan Undang-Undang No. 20 Tahun 2003 Tentang Sistem Pendidikan Nasional mengatur bahwa Pendidikan Anak Usia Dini (PAUD) dapat diselenggarakan melalui jalur formal, nonformal, dan informal (Pasal 28 ayat 2) UU Tahun 2003 ini telah mendorong tumbuhnya lembaga PAUD dalam berbagai bentuk layanan dengan kualitas yang sangat beragam. Kelembagaan tersebut dimaksudkan untuk memenuhi kebutuhan masyarakat akan layanan PAUD (Wijania, 2014:4). Dengan berkembangnya lembaga PAUD yang ada, maka Tahun 2009 dikeluarkan Permendiknas No. 58 Tahun 2009 Tentang Standar Pendidikan Anak Usia Dini, meliputi pendidikan formal dan nonformal yang terdiri atas: Standar Tingkat Pencapaian Perkembangan, Standar Pendidik dan tenaga Kependidikan, Standar Isi, Proses dan Penilaian, serta Standar Sarana dan Prasarana, Pengelolaan dan Pembiayaan (Wijania, 2014:4).

Menindak lanjuti Permendiknas No. 58 Tahun 2009 tersebut, Dinas Pendidikan Provinsi Bali mulai mensosialisasikan tentang PAUD yang merupakan induk dari Taman KanakKanak (TK), Kelompok Bermain (KB), Taman Penitipan Anak (TPA), dan Satuan PAUD Sejenis (SPS). Sosialisasi tentang PAUD ini diteruskan di Tingkat Kota dan ditindak lanjuti oleh Dinas Dikpora Kecamatan Denpasar Utara. Sosialisasi tentang PAUD ini semakin diperkuat dengan terbitnya Permendiknas No. 36 Tahun 2010 Tentang Organisasi dan Tata Kerja Kementrian Pendidikan Nasional, Direktorat Pendidikan Anak Usia Dini, membina layanan program Taman Kanak-Kanak (TK), Kelompok Bermain (KB), Taman Penitipan Anak (TPA), dan Satuan PAUD Sejenis (SPS) (Wijania, 2014:5).
Mengingat di zaman sekarang banyak di televisi, media cetak atau yang sebagainya telah disiarkan banyaknya kasus yang menyimpang, dimana-mana terjadi kekerasan, pelecehan seksual, korupsi para pejabat dan lain sebagainya yang sangat meresahkan masyarakat, terbukti bahwa semakin merosotnya karakter bangsa ini. Selaras dengan hal tersebut di atas, maka terbentuklah sebuah tempat yang bertujuan untuk mencerdaskan putra-putri bangsa dengan lebih mengutamakan karakter baik dari anak, yaitu PAUD Sai Prema Kumara Tonja Denpasar. Pertimbangannya adalah "apalah arti dari sebuah kepandaian apabila tidak diimbangi dengan karakter yang baik" atau disingkat dalam motto "The end of education is character". Tujuan luhur ini diwujudkan dengan mengembangkan suatu model pembelajaran, yaitu educare, yang difokuskan pada karakter siswa sesuai bakatnya masing-masing.

Dari sisi humanistik, penerapan educare memiliki alasan memanusiakan manusia. Faktor humanistik mengembangkan sifat-sifat kemanusiaan manusia, dalam hal ini siswa pada PAUD Sai Prema Kumara. Prinsipnya adalah manusia telah memiliki kemampuan dasar yang dapat dikembangkan semaksimal mungkin melalui proses belajar (Blackburn, 2013: 413). Inilah salah satu alasan penerapan ajaran agama Hindu melalui educare pada PAUD Sai Prema Kumara.

Melalui penerapan ajaran agama Hindu melalui educare, PAUD Sai Prema Kumara telah dapat menjawab keresahan masyarakat dalam menanggapi segala situasi dan kondisi zaman saat ini (Kaliyuga). Masyarakat disini meliputi warga yang tinggal di sekitar lingkungan sekolah, orang tua siswa, masyarakat pemerhati pendidikan, pengusaha dan beberapa instansi pemerintah dan swasta. Terlebih lagi, masyarakat tersebut memberikan dukungan dan kontribusi yang sangat tinggi terhadap lembaga, karena selama ini lembaga menorehkan banyak prestasi, melakukan kegiatan inspiratif, dan juga melakukan program-program yang bermanfaat bagi masyarakat (Wijania, 2014:10).

PAUD ini dapat dipandang sebagai salah satu solusi dalam menyelesaikan masalah yang meresahkan masyarakat. Dapat terlihat pada media-media, baik cetak maupun elektronik 
saat ini, penuh dengan pemberitaan tentang perbuatan yang tidak bermoral, seperti kekerasan fisik, kekerasan seksual, tawuran, korupsi dan banyak lagi perilaku yang jauh dari karakter baik. Maksud dari pendidikan yang berbasis pada pembentukan karakter ini adalah supaya ketika anak-anak (siswa) ini dewasa dan menjadi warga masyarakat diharapkan mereka mampu menggunakan pengetahuan dan skill mereka untuk mensejahterakan masyarakat bukan sebaliknya untuk menyakiti masyarakat.

Jika dipertimbangkan sekali lagi, penerapan model pembelajaran educare di PAUD Sai Prema Kumara sangat banyak bersesuaian dengan ajaran agama Hindu, sudah tentu terdapat alasan religius di dalamnya. Sudah sangat dipahami bahwa ajaran agama Hindu memiliki makna yang sangat universal, sehingga sangat mudah dan efektif untuk diterapkan. Wijania, wawancara tanggal 21 Mei 2020, Kepala PAUD Sai Prema Kumara, menuturkan:

"Alasan penerapan ajaran agama Hindu melalui model pembelajaran educare di PAUD Sai Prema Kumara, karena pendidikan karakter sekarang ini jarang ditemukan terutama pendidikan agama Hindu jarang ditemukan secara intens di lingkungan keluarga. Padahal yang bertangguung jawab seharusnya adalah keluarga, sementara kondisi sebagian keluarga memiliki kesibukan, terutama orang tua yang disibukkan dengan pekerjaan/karir, sehingga pendidikan karakter sangat jarang ditemukan dalam keluarga" (wawancara tanggal 21 Mei 2020).

Penuturan Wijania tersebut menegaskan bahwa di zaman globalisasi ini sangat diperlukannya pendidikan karakter untuk anakanak bangsa, orang tualah yang menjadi peran yang penting dalam keluarga dalam membentuk karakter anaknya. Namun, pada kenyataan saat ini sebagian besar orang tua sering meninggalkan rumah dan anaknya demi urusan pekerjaan. Selain itu, globalisasi saat ini telah membawa berbagai dampak bagi generasi muda baik dampak positif, maupun dampak negatif.

Sumawati, salah seorang Guru PAUD Sai Prema Kumara, kembali menegaskan:
"Karena jarangnya pendidikan karakter diterapkan di lingkungan keluarga, maka sekolah ini concern menerapkan pendidikan karakter, karena kalau dibiarkan semua generasi tidak tahu tentang agama, tentang karakter apalah jadinya mereka. Kalau semua generasi muda begitu hancurlah bangsa dan negara ini. Jadi dari sini kita mempunyai mimpi besar mudah-mudahan dari salah satu anak di sini bisa menjadi pemimpin, terutama menjadi orang baik di masyarakat, yang bisa menginspirasi yang lain, terutama dia harus bisa merubah dirinya menjadi baik dulu, dengan begitu kita berharap walaupun dia tidak bisa merubah masyarakat tetapi setidaknya bisa merubah dirinya sendiri. Karena sekolah ini sangat mengajegkan nilai-nilai agama Hindu" (wawancara 12 Mei 2020).

Penuturan Sumawati tersebut kembali menegaskan bahwa alasan diterapkannya pembelajaran berbasis educare di PAUD Sai Prema Kumara, karena jarangnya pendidikan karakter diterapkan di lingkungan keluarga, maka dari itu PAUD ini lebih menekankan kepada pendidikan karakter siswa, yang lebih diutamakan dalam PAUD ini adalah terbentuknya karakter baik dari anak dan mencetak anak agar menjadi anak yang berkarakter baik dan berbudi luhur, serta mengamalkannya secara religius. Bagi pihak PAUD Sai Prema Kumara Tonja, sekolah ini tidak hanya semata-mata untuk membentuk karakter peserta didik agar baik, tapi juga religius. Sekolah ini juga dianggap sebagai sarana berbagi pengalaman kepada generasi muda, khususnya anak-anak berusia 3 sampai 7 tahun. Sekali lagi dijelaskan oleh ibu guru Sumawati bahwa apalah artinya manusia yang pintar apabila tidak memiliki karakter baik dan tidak pernah mengamalkan ajaran-ajaran agama Hindu dalam hidupnya. Artinya, para guru pada PAUD Sai Prema Kumara tidak hanya semata-mata menunaikan tugasnya sebagai guru PAUD secara profesional, tapi sekaligus juga menunaikan tugas religius, yaitu untuk menularkan nilai-nilai kehinduan melalui penerapan educare. Oleh karena itu dapat 
dipahami bahwa PAUD Sai Prema Kumara tidak hanya semata-mata menjadi lembaga pendidikan, tapi juga perpanjangan tangan dari agama Hindu, yang sesuai dengan kultur masyarakat di Bali demi tujuan religius.

\subsection{Penerapan Pendidikan Karakter Berbasis Educare di PAUD Sai Prema Kumara Denpasar}

Seperti telah dijelaskan sebelumnya berdasarkan observasi dan wawancara ditemukan bahwa secara interpretatif educare tidak jauh berbeda prinsip-prinsip dalam hinduisme, secara lebih spesifik yang dimaksud adalah pembelajaran berbasis yoga, tri kaya parisudha, karmaphala dan prema. Yoga berkaitan dengan disiplin dan konsentrasi siswa, tri kaya parisudha 'tiga laku bajik' diterjemahkan ke dalam praksis sehari-hari, karmaphala 'perbuatan pasti berhasil' dan prema 'cinta kasih' adalah nilai yang selalu menjadi pegangan. Adapun yoga dimaksud adalah yama 'pengendalian sikap eksternal', niyama 'pengendalian sikap internal', asana 'sikap yang baik dan benar', pranayama 'mengatur nafas', pratyahara 'membalik perhatian ke dalam diri', dharana 'mencari titik konsentrasi', dhyana 'kontemplasi dengan titik konsentrasi' dan samadhi 'meditasi'. Dalam penerapannya, kembali ditegaskan bahwa siswa adalah anak-anak berusia 3 sampai 6 atau 7 tahun, oleh karena itu, dibutuhkan strategi khusus.

Pertama-tama dalam pembentukan karakter diri siswa strategi yang diterapkan sangat mirip dengan delapan tahapan yoga yang disebut astanggayoga. Yang menjadi dasar pembentukan karakter disiplin dan etis adalah yama, terutama adalah ahimsa 'tidak menyakiti/membunuh'. Adapun strategi penerapan ajaran ahimsa yang diterapkan di PAUD Sai Prema Kumara adalah pertama, tentunya guru memberikan pemahaman kepada siswanya bahwa perbuatan menyakiti (himsa) tidak boleh dilakukan karena menyakiti adalah perbuatan yang dosa dan Ida Sang Hyang Widhi akan marah kalau ada umatnya yang suka menyakiti apalagi sampai membunuh. Kedua, selain memberikan pemahaman, hal yang tidak kalah penting adalah praktek dari ajaran ahimsa tersebut yaitu tidak menyakiti teman, tidak bertengkar dengan teman, menyayangi lingkungan dengan membuang sampah pada tempatnya. Di PAUD Sai Prema Kumara, Tonja, Denpasar Utara karakter ahimsa dibangun dan dipupuk dengan penciptaan lingkungan belajar ramah, bersih, aman, membahagiakan, tidak membedabedakan teman, dan keteladanan dari pihak sekolah yang diwakili oleh guru. Terlebih lagi, boleh dikatakan, guru-guru di PAUD Sai Prema Kumara sama sekali tidak pernah menggunakan kekerasan dalam mendidik para siswa PAUD.

Berdasarkan observasi, selain keteladanan, juga diterapkan strategi penggunaan bahasa atau komunikasi yang santun, semisal ketika terdapat siswa yang membandel dan tidak mau masuk kelas, seorang guru tidak menegurnya dengan kata "jangan" atau "tidak boleh", tapi ia lebih memilih "anak ibu baik sekali, atau anak ibu pintar sekali, pasti sekarang masuk kelas" lalu bersabar menunggu anak didiknya dengan senantiasa mengajak untuk masuk kelas. Inilah yang disebut educare, yaitu education 'pendidikan' dengan berlandaskan care 'kepedulian'. Dengan demikian, dapat dipahami bahwa jika pihak sekolah menciptakan lingkungan ahimsa, maka anak didik akan terarah menjadi anak yang ahimsa 'tidak menyakiti'. Dengan begitu, di masa depan anak didik memiliki kemungkinan yang sangat besar menjadi anak yang anti kekerasan.

Kemudian, bagian yama dalam astangga yoga yang diterapkan di PAUD Sai Prema Kumara adalah satya 'perbuatan yang jujur/setia kepada semua makhluk'. Berdasarkan pemahaman yang diberikan di PAUD, satya terdiri dari beberapa macam yaitu, jujur/setia kepada Ida sang Hyang Widhi, jujur/setia kepada kata hati, jujur/setia kepada ucapan, jujur/setia kepada teman dan jujur/setia kepada perbuatan. Strategi dari penerapan ajaran satya adalah guru selalu mengingatkan siswanya baik itu di kelas ataupun di luar kelas bahwa perbuatan yang jujur adalah perbuatan yang disayang oleh Ida Sang Hyang Widhi Wasa, disayang oleh semua orang termasuk orang tua dan guru di sekolah. Kedua, selain dengan memberikan penuturan atau pemahaman alangkah baiknya jika siswa langsung diajak mempraktekan atau menerapkannya dalam kehidupan sehari-hari, 
yaitu tidak boleh ingkar janji, tidak boleh berbohong kepada orang tua, guru di sekolah, teman dan orang-orang di sekitar. Begitu juga pihak sekolah, para guru memberikan feedback atau umpan balik terhadap segala tugas yang diberikan siswa yang seringkali diawali dengan pujian, "Anak ibu luar biasa sekali gambarnya, coba tambah sedikit warna merah pada bagian ini, pasti lebih bagus." Di akhir masa pembelajaran, para orang tua siswa satu per satu diberi pemahaman mengenai perkembangan anak-anaknya selama masa belajar, agar mereka memiliki gambaran dan memiliki tugas moral membimbing anaknya di rumah agar memperoleh hasil yang diharapkan.

Ajaran agama Hindu yang ketiga diterapkan di PAUD Sai Prema Kumara adalah ajaran asteya. Asteya adalah perbuatan yang tidak mengambil barang milik orang lain atau disebut dengan tidak mencuri. Di PAUD Sai Prema Kumara ini siswanya diajarkan agar tidak pernah mengambil milik orang lain tanpa sepengetahuan pemiliknya. Adapun strategi dari penerapan asteya adalah pertama, guru di sekolah selalu memberikan bimbingan dan arahan baik itu di dalam kelas ataupun di luar kelas mengenai perbuatan mencuri adalah perbuatan yang tidak baik. Hal yang ditekankan kepada siswa adalah bahwa orang yang suka mencuri atau mengambil barang tanpa sepengetahuan pemiliknya adalah perbuatan yang tidak disukai oleh Ida Sang Hyang Widhi. Strategi kedua adalah dengan menonton video mengenai perbuatan yang melanggar prinsip-prinsip asteya. Dan strategi ketiga, tentunya adalah praktek atau menerapkan langsung dalam kehidupan sehari hari, yaitu memiliki barang pribadi di sekolah yang seringkali ditandai dengan pemberian nama pemilik seperti sandal, gelas, sikat gigi, pensil warna, dan sebagainya. Jikapun kemudian siswa menginginkan/mengambil sesuatu/ barang agar selalu meminta ijin dulu kepada pemiliknya baik itu temannya sendiri atau gurunya. Begitu juga sekolah dan guru menerapkan hal yang sama, yaitu ketika siswa sudah menyelesaikan masa belajarnya, sekolah melalui guru pasti mengembalikan seluruh barang-barang yang dimiliki siswa, baik berupa sandal, crayon, buku-buku mewarnai, hasil keterampilan tangan, dan karya-karya lainnya selama melaksanakan pembelajaran di PAUD Sai Prema Kumara.

Seperti telah dijelaskan di atas bagian yama dalam astangga yoga yang diterapkan di PAUD adalah ahimsa, satya, dan asteya. Sedangkan bramacarya 'tidak mengumbar nafsu' dan aparigraha 'tidak menerima pemberian yang tidak penting' belum terlalu ditekankan atau tidak terlalu menonjol mengingat siswa adalah anak usia dini. Setrategi yang digunakan seringkali berupa pembagian makanan atau snack yang dibuat langsung di sekolah yang dibagikan secara adil dan merata. Selain itu, di sekitar lingkungan PAUD Sai Prema Kumara tidak terdapat kantin. Yang ditekankan adalah para siswa bila perlu membawa bekal makanan ringan dari rumah (seringkali tanpa kandungan daging, vegetarian, khusus di sekolah) dan tentu saja air minum pribadi.

Selanjutnya adalah bagian niyama. Berdasarkan observasi, yang menonjol diajarkan adalah sauca 'menjaga kebersihan dan kesucian diri'. Strategi penerapannya adalah dengan selalu mengingatkan siswa berulang-ulang untuk mencuci tangan, menyikat gigi, menyiram kotoran atau koncing sesuai anjuran (biasanya tiga kali atau gayung), membersihkan kaki setelah bermain sebelum masuk kelas di wastafel (berjejer panjang agar anak tidak rebutan) dan kamar mandi yang sudah disediakan.

Lalu, santosa 'puas dengan apa yang datang dengan wajar'. Artinya, setiap orang hendaknya selalu bersyukur dengan apa yang diperolehnya, baik itu dalam ukuran besar maupun kecil. Di PAUD Sai Prema Kumara siswanya diajarkan agar selalu merasa puas dan besyukur atas apa yang dimilikinya serta jauh dari rasa iri hati, dengki. Adapun strategi dari penerapan ajaran santosa adalah pertama, tentunya sebagai seorang guru memiliki tugas untuk selalu mengingatkan siswanya untuk selalu merasa puas dan selalu bersyukur. Kemudian strategi yang kedua adalah, pengamalan dari apa yang telah disampaikan oleh guru di sekolah yaitu mempraktekkan langsung dalam kehidupan sehari-hari dengan selalu membiasakan diri untuk selalu bersyukur dan berterima kasih atas apa yang telah diperoleh, seperti berdoa sebelum dan sesudah makan. Begitu halnya 
penerapan tapa 'disiplin diri' dan swadyaya 'kemandirian belajar' dengan selalu menekankan untuk tepat waktu dan melakukan segala hal yang menjadi minat siswa sejak awal (biasanya diberi pilihan oleh guru yang kemudian ditekuni siswa secara mandiri) dengan bimbingan langsung oleh para guru.

Kemudian, bagian niyama yang paling ditekankan juga di PAUD Sai Prema Kumara adalah ajaran Isvarapranidhana 'memusatkan pikiran dan bhakti kepada Tuhan YME'. Adapun strategi dari penerapan ajaran isvarapranidhana adalah pertama, guru akan selalu memberikan tuntunan dan membimbing siswanya untuk selalu berdoa sebelum ataupun sesudah melakukan sesuatu. Kedua, para siswa mengamalkannya langsung dalam kehidupan sehari hari, seperti sebelum belajar siswa akan melakukan Tri Sandhya/Mantram Gayatri, melakukan persembahyangan saat Purnama dan Tilem, serta di hari-hari suci lainnya seperti Saraswati.

Selanjutnya bagian astangga yoga yang penting diterapkan adalah asana 'sikap duduk yang dituntun menjadi sikap yang kuat dan menyenangkan' Sikap yang baik tentu saja diberlakukan dalam segala bentuk kegiatan. Namun, pelatihan pembiasaan itu terutama diterapkan pada saat 'duduk hening'. Adapun strategi penerapan ajaran Asana adalah sebelum memulai pelajaran yaitu jam 08.00-09.00, siswa setiap harinya selalu diajak untuk selalu duduk hening dengan memusatkan pikiran kepada Yang Maha Pencipta, dalam hal ini ditekankan sesuai istilah yang digunakan oleh umat Hindu Bali, yaitu Ida Sang Hyang Widhi Wasa.

Tidak hanya sampai di situ, asana kemudian dilanjutkan dengan pranayama 'mengatur nafas (wajar dan alami)' dan pratyahara 'membalik perhatian indera'. Hal tersebut ditunjukkan dengan sikap duduk silasana 'sikap duduk bersila sempurna' dengan mata terpejam sebagian dan tahan godaan terhadap segala gangguan dari luar. Dalam kondisi tersebut, guru menghidupkan lilin sambil memberi instruksi secara perlahan berupa kalimatkalimat penuntun, seperti "pusatkan pikiran kepada cahaya lilin yang menyala di depan anakanak, sehingga tepat berada di antara kedua mata. Lalu biarkan cahaya itu memasuki tubuh anak-anak." Seringkali juga diberi tekanantekanan dalam tiga tahap, seperti "aku di dalam cahaya", "cahaya di dalam hatiku", dan "aku adalah cahaya". Ketiga tahap ini tidak berbeda dengan prinsip dharana 'memusatkan pikiran pada sasaran (cahaya)', dhyana 'pikiran tidak tergoyahkan selain kepada cahaya', dan samadhi 'pikiran menyatu dengan objeknya (cahaya)'. Oleh karena itu seringkali kegiatan yang dilaksanakan setiap hari sebelum pembelajaran ini disebut "meditasi cahaya'. Tuntunan meditasi yang diberlakukan di PAUD Sai Prema Kumara dapat diakses di channel Youtube, "Meditasi Cahaya Sathya Sai". Dalam meditasi atau penerapan yoga tersebut juga ditekankan beberapa arahan, seperti "sebarkan cahaya ke lidah, agar berkata yang baik".
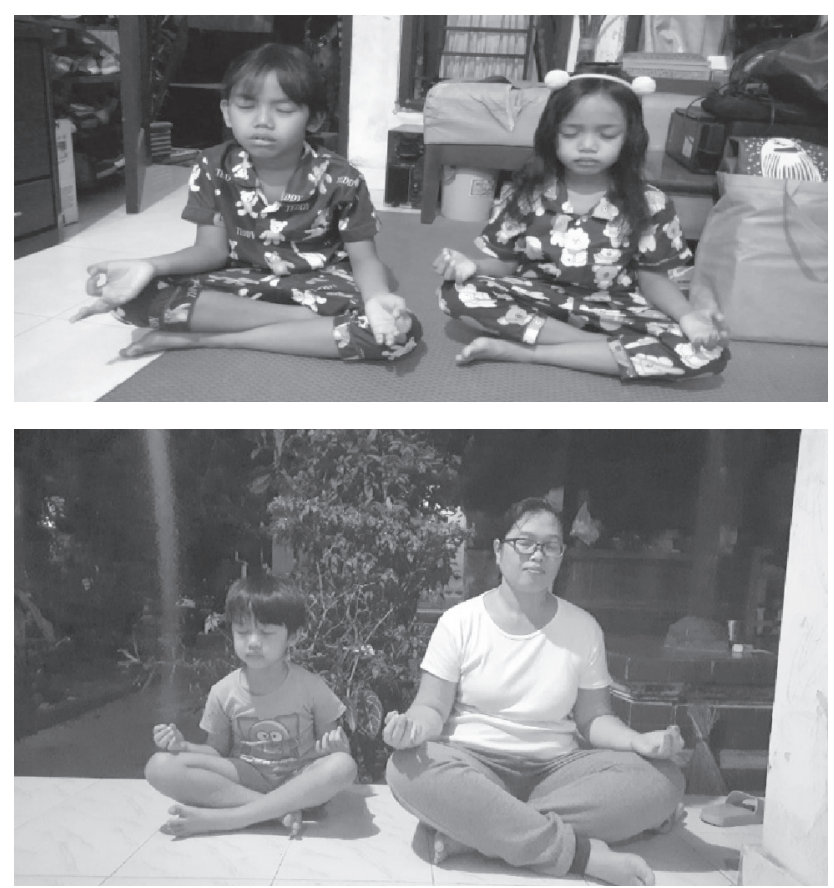

Gambar 3.1. Pelaksanaan Meditasi Cahaya di Rumah

Selain itu, pada saat meditasi prinsip-prinsip seperti berpikir, berkata, berbuat yang baik ditekankan terus-menerus. Seperti terlihat pada gambar di atas, para siswa tidak saja melaksanakan meditasi cahaya secara individual, tetapi juga melibatkan orang tua. Begitu juga dengan prinsip-prinsip bahwa segala perbuatan baik pasti berbuah baik, tidak hanya berlaku bagi siswa, tetapi juga bagi guru dan orang tua. Seluruh perbuatan baik itu disebut dengan prema 'cintai semua, layani 
semua' yang seringkali didendangkan dalam lagu "Belajar dari Matahari". Hal ini membentuk semacam antikateksis individual yang membendung segala kateksis yang merugikan bagi proses pembentukan karakter siswa (bdk. Hall, 2019:82). Jadi siswa nantinya memiliki ego yang sesuai dengan ideal-ideal yang berlaku di masyarakat.

Selain mengikuti proses pembelajaran, para orang tua juga diberi pelatihan menjadi orang tua yang baik dalam program parenting bulanan, seperti dalam gambar di bawah ini.

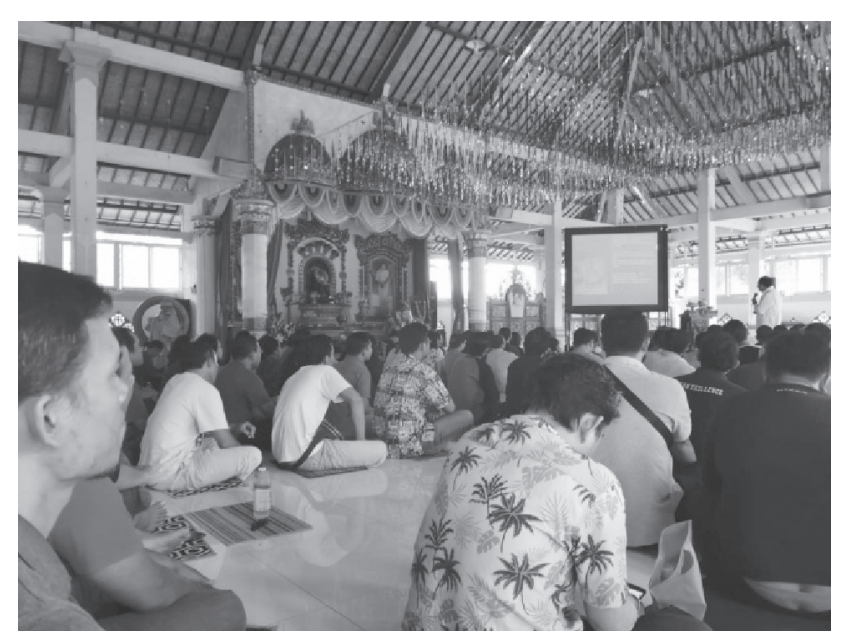

Gambar 3.2. Acara Parenting Bulanan Orang Tua Siswa

Dalam kegiatan parenting dimaksud para orang tua mendengarkan materi presentasi dari seorang atau lebih narasumber, seringkali seorang guru dari sekolah-sekolah berprestasi, psikolog, dan para ahli di bidang pendidikan. Tidak hanya mendengarkan, para orang tua proaktif mengajukan keluhan dan pertanyaan seputar dinamika keterlibatannya dengan anaknya dalam proses pembentukan karakter siswa di rumah. Selain itu, para orang tua juga seringkali saling bertukar pengalaman dalam menanggulangi segala permasalahan dalam mendidik anak di rumah. Namun yang paling ditekankan oleh para narasumber dan sekolah adalah orang tua harus menjadi contoh ideal bagi anak-anaknya.

Secara psikoanalisis, strategi yang diterapkan tersebut dapat disejajarkan dengan strategi pembentukan ego-ideal. Seperti dijelaskan oleh Hall (2019:83) bahwa energi-energi ditanamkan dalam pengkateksisan ideal-ideal yang merupakan representasi-representasi yang diinternalisasi dari nilai-nilai moral orang tua. Menurut Freud, ego-ideal ini menciptakan seorang idealis dan berbudi luhur. Dengan mengidentifikasi diri pada ragam objek pilihan etis yang dimiliki ego-ideal, ego (siswa) merasakan semacam kebanggaan. Sebagai contoh, seorang anak yang mampu melakukan sesuatu seperti dilakukan orang tuanya merasakan kebanggaan pribadi yang luar biasa.

Pada prinsipnya, dalam penerapan educare, semua pihak yang berhubungan dengan siswa, seperti guru dan keluarga, dilibatkan dalam proses pembelajaran terutama untuk pembentukan karakter. Pihak-pihak yang terlibat merupakan semacam role model bagi siswa yang nantinya dapat dipedomani dalam bersikap dan berprilaku. Dengan demikian dapat dikatakan bahwa pendidikan yang dikembangkan lebih difokuskan pada aspek afektif, yaitu pada sikap, namun juga tidak serta merta mengesampingkan aspek kognitif dan psikomotor.

\section{PENUTUP}

Pendidikan karakter berbasis educare merupakan suatu penerapan model pembelajaran yang diterapkan di PAUD Sai PremaKumaraDenpasardalammengembangkan potensi anak yang dibawa sejak lahir dengan membangkitkan minat dan bakat dari anak tersebut. Prinsip dasarnya adalah seorang anak/ siswa sudah memiliki minat dan bakat tersendiri terhadap sesuatu. Bagi pihak PAUD Sai Prema Kumara Tonja, sekolah ini tidak hanya sematamata untuk membentuk karakter peseta didik agar baik, tapi juga religius. Sekolah ini juga dianggap sebagai sarana berbagi pengalaman kepada generasi muda, khususnya anak-anak berusia 3 sampai 7 tahun.

Karakter tersebut diterjemahkan ke dalam prinsip disiplin diri dan meditasi melalui yoga, prilaku bajik melalui praksis berpikir, berkata, dan berbuat yang baik, penanaman bahwa segala perbuatan pasti berbuah, dan penanaman nilai-nilai cinta kasih sebagai yang paling utama. Pendidikan karakter berbasis educare diterapkan melalui beberapa strategi, yaitu strategi yoga atau praktik astangga yoga, 
keteladanan guru, dan keterlibatan keluarga atau orang tua dalam proses pembelajaran. Dengan begitu, terjadi semacam mekanisme pembentukan antikateksis individual dan egoideal yang diteladani dari guru dan orang tua yang terlatih untuk mendidik karakter.

\section{DAFTAR PUSTAKA}

Arikunto, Suharsimi. 2006. Prosedur Penelitian Suatu Pendekatan Praktek. Jakarta: Rineka Cipta.

Cahyaningrum, Eka Sapti, dkk. 2017. 'Pengembangan Nilai-nilai Karakter Anak Usia Dini Melalui Pembiasaan dan Keteladanan'. Artikel dalam Jurnal Pendidikan Anak Vol. 6 Edisi 2 Desember 2017. Yogyakarta: Universitas Negeri Yogyakarta.

Center, Sri Sathya Sai. 1988. Pendidikan Nilai-Nilai Kemanusiaan untuk Jaman Baru. Jakarta:Yayasan Sri Sathya Sai Indonesia.

Chaplin, J.P. 2000. Kamus Lengkap Psikologi. Jakarta: Raja Grafindo Persada.

Gulo, W. 2004. Metodologi Penelitian. Jakarta: PT. Grasindo.

Hall, Calvin S. 2019. Psikologi Freud: Sebuah Bacaan Awal. Yogyakarta: IRCiSoD.

Hamalik, Oemer. 2004. Proses Belajar Mengajar. Jakarta: Bumi Aksara.

Iqbal, Hasan. 2002. Metodologi Penelitian dan Aplikasinya. Jakarta: Ghalia Indonesia.

Kesuma, Dharma dkk. 2010. Pendidikan Karakter Kajian Teori dan Praktik di Sekolah. Bandung: PT. Remaja Rosdakarya.

Koentjaraningrat. 1981. Metode-Metode Penelitian Masyarakat. Jakarta: PT. Gramedia Pustaka.

Lestari, Sri. 2012. Metodologi Penelitian. Jakarta: Bumi Aksara.

Nucci, Larry P. dan Darcia Narvaez. 2014. Pendidikan Moral dan Karakter. Bandung: Nusa Media.

Rohman, Arif. 2011. Memahami Pendidikan dan Ilmu Pendidikan. Yogyakarta: LaksBang Mediatama.

Sai, Yayasan Sri Sathya. 2016. Pendidikan Nilai-Nilai Kemanusiaan. Medan: Yayasan Sri Sathya Sai Baba Indonesia.

Silahuddin. 2017. 'Urgensi Membangun Karakter Anak Usia Dini.' Artikel dalam Bunnaya: Jurnal Pendidikan Anak Vol. III, No. 2, Juli 2017. Banda Aceh: Prodi Pendidikan Islam Anak Usia Dini, Universitas Ar-Raniry Darussalam.

Subagyo, Jiko. 2004. Metode Penelitian Suatu Metode dan Praktek. Jakarta: Reika Cipta.

Sugiyono. 2014. Metode Penelitian Pendidikan Pendekatan Kuantitatif, Kualitatif, dan R\&D. Bandung: Alfabeta.

Suija, I Wayan. 2012. Pendidikan Karakter dalam Upaya Meningkatkan Karakter Bangsa. Dalam Widyanatya. Vol 2. No.1.

Sura, I Gede dan I Wayan Sukayasa. 2009. Samkya dan Yoga. Denpasar: Widya Dharma.

Suryobroto, B. 1990. Beberapa Aspek Dasar Kependidikan. Jakarta: Rineka Cipta.

Suyanto, Slamet. 2012. 'Pendidikan Karakter untuk Anak Usia Dini.' Artikel dalam Jurnal Pendidikan Anak Vol. 1, Edisi 1, Juni 2012. Yogyakarta: Universitas Negeri Yogyakarta.

Tim Dosen Agama Hindu Unud. 2009. Pendidikan Agama Hindu di Perguruan Tinggi. Denpasar: Udayana University Press.

Tim Penyusun. 2012. Dasar-Dasar Kependidikan. Jakarta: Direktorat Jendral Bimbingan Masyarakat Hindu Kementrian Agama RI.

Wijania, I Wayan. 2014. Profil Lembaga PAUD Sai Prema Kumara. Denpasar. 
Pemerintah Kota Denpasar Dinas Pendidikan Pemuda dan Olahraga UPTD Dikpora Kecamatan Denpasar Utara.

Wulandari, A.A. Istri Mas, dkk. 2014. 'Studi Evaluatif Implementasi Pendidikan Karakter Berbasis Nilai-nilai Kemanusiaan pada Anak Usia Dini di PAUD Sai Prema Kumara Denpasar.' Artikel dalam E-Journal Program Pascasarjana. Singaraja: Universitas Pendidikan Ganesha Program Studi Administrasi Pendidikan. 